\title{
Effect of Post-Harvest Traditional Technologies on the Nutrient Content and Antioxidant Compounds of Defatted Flours from Ricinodendron heudelotti (Baill. Pierre ex Pax) Seed Kernels
}

\author{
Mamadou Coulibaly ${ }^{1}$, Camille Adam Kouamé ${ }^{1,2}, *$ (D) Denis Yao N'dri ${ }^{1}$, \\ Nestor Kouakou Kouassi ${ }^{1}$, Kingsley Kwadwo Asare Pereko ${ }^{3}$ (D) and Georges N'guessan Amani ${ }^{1}$ \\ 1 Food Biochemistry and Tropical Products Technology Laboratory, Biochemistry and Food Technology \\ Section, Department of Food Science and Technology, University Nangui Abrogoua, P.O. Box 801 Abidjan 02, \\ Cote d'Ivoire; coulismad@yahoo.fr (M.C.); ndri_denis@yahoo.fr (D.Y.N.); nestorkksi@yahoo.fr (N.K.K.); \\ amanigeorges@yahoo.fr (G.N.A.) \\ 2 Food Biochemistry and Tropical Products Technology Laboratory, Nutrition Section, Department of Food \\ Science and Technology, University Nangui Abrogoua, P.O. Box 801 Abidjan 02, Cote d'Ivoire \\ 3 Department of Community Medicine, School of Medical Sciences, PMB University of Cape Coast, Cape \\ Coast, University Post Office, University Avenue Central Region, Ghana 00233; Ghana kpereko@gmail.com \\ * Correspondence: kadamcamille@gmail.com; Tel.: +225-0776-5139 or +225-4005-1817
}

Received: 7 February 2018; Accepted: 13 March 2018; Published: 22 March 2018

\begin{abstract}
Akpi (Ricinodendron heudelotii) is a semi-deciduous plant species indigenous to the coastal nations of West Africa. Its kernels are rich in nutrients and bioactive compounds. In this article, we performed a nutritional characterization and a phytochemical composition of defatted kernel flours from Ricinodendron heudelotti that were grown in six different regions of Cote d'Ivoire. Classical analytic methods were used to determine the chemical composition. There were significant differences between the samples for all the parameters studied; in addition, both the locality of production and the Ricinodendron heudelotii seed kernels extraction systems showed a noteworthy influence on the mineral and element composition of the defatted flours. The samples were also rich in protein $(47.0-61.3 \%)$ and energy (330.4-339.2 kcal/100 g). Magnesium (12.0-40.0\%) was found to be the predominant mineral. Polyphenols $(216.6-403.9 \mathrm{mg} / 100 \mathrm{~g})$ and oxalates $(714.7-972.9 \mathrm{mg} / 100 \mathrm{~g})$ were the main phytochemical compounds identified. The consumption of defatted kernel flours from Ricinodendron heudelotti may contribute relatively high intake levels of protein, carbohydrate, and mineral macro- and micronutrient $(\mathrm{K}, \mathrm{Mg}, \mathrm{Ca}, \mathrm{Mn}$, and $\mathrm{Fe})$. By performing principal coordinate analysis, the multidimensional scaling plot classified the defatted flours according to the kernel extraction into four main extraction systems: Bondoukou-Lakota-Vavoua diagram, Agboville1 diagram, Divo diagram, and Agboville2 diagram.
\end{abstract}

Keywords: Akpi; antioxidant compounds; food analysis; food composition; multidimensional scaling; mineral and trace elements; Ricinodendron heudelotti; traditional extraction method

\section{Introduction}

Among the species of non-timber forest products (NTFPs), several wild fruits and vegetables are consumed in Africa and particularly in Cote d'Ivoire (West Africa) [1]. These wild fruits and vegetables contribute significantly to covering rural nutritional needs and represent a source of income for the household [2]. One of these wild fruits and vegetables is the Ricinodendron heudelotii (Baill. Pierre ex Pax), a member of the Euphorbiaceae family. The plant is known to have two subspecies, namely, heudelotii and africanum (Müller of Aargau, Müll. Arg.) [3]. Subspecies heudelotii is known to occur 
in Senegal and Benin, while the subspecies africanum is located in the southern part of Nigeria and South Africa. The subspecies Ricinodendron heudelotii ( $R$. heudelotti) is the only one encountered in Cote $\mathrm{d}$ 'Ivoire. $R$. heudelotti species is a fast-growing tree, reaching up to $50 \mathrm{~m}$ in height and $2.7 \mathrm{~m}$ in girth or a diameter of $150 \mathrm{~cm}$, which grows in the tropics. In Sub-Saharan Africa, it is one of the main trees of the tropical forest in the equatorial region. The tree has several local names such as "Akpi" in Cote d'Ivoire, "Njansang" in Cameroon, "Okwe" in south east Nigeria, "Bomoko" in Central Africa Republic, and "Betratra" in Madagascar [4]. The edible part of the fruit (kernel) is rich in lipids (47.8-50\%) but also contains proteins (22.38-24.91\%), phosphorus (1693 mg/100 g), calcium (1013 mg/100 g), potassium $(811.4 \mathrm{mg} / 100 \mathrm{~g})$, and magnesium $(528.6 \mathrm{mg} / 100 \mathrm{~g})$ [4,5]. As for bioactive compounds from the seeds of R. heudolotti, their defatted flours contain $940.0 \mathrm{mg} / 100 \mathrm{~g}$ of polyphenolic compounds, $17.57 \mathrm{mg} / 100 \mathrm{~g}$ phytates, and $2690.9 \mathrm{mg} / 100 \mathrm{~g}$ of oxalates and may be responsible of the numerous pharmacological properties [6]. From a nutritional point of view, the amino acids of protein from $R$. heudelotii defatted kernel flour are of the same level according to Tchiégang et al. [7]. In the human diets, proteins are obtained from animal and plant sources, and $R$. heudelotii defatted flour can be used as an alternative source of protein from plant origin as much as cereal and legumes [8]. Several kernel extraction technologies exist independently of production areas. The kernels from $R$. heudelotii fruits, widely consumed, arise out of the ability of women. Generally, drupes that fall-down from the trees are piled and left to ferment for two weeks or more to enable the pulp to rot. Once rotten, the seeds are extracted after washing and boiling steps. An additional boiling of the seeds is then necessary to soften them and enable cracks to appear in the shells. After this, the kernel is removed from the seed using a knife or any other sharp thing. The kernels are dried in the sun or in an oven and can be stored for several years. They may be sold throughout the year in urban markets [9]. Studies of post-harvest and processing technologies for fruits, nuts, and kernels showed that the kernel extraction system is one of the chemical and nutritional property factors of food variation [10]. Despite the increasing number of scientific reports on the $R$. heudelotti [11-13], studies of the overall nutritional quality of defatted seeds from Cote d'Ivoire are few. With the aim of valorising defatted flours, knowledge of its nutrients and some anti-nutrient composition with respect to the traditional extraction process need to be generated. The objectives of this study, therefore, was to investigate the nutrients, minerals, phytochemical, and bioavailability of defatted flours from $R$. heudelott $i$ seed kernels grown in six producing areas of Cote d'Ivoire. In this study, the effect of the traditional kernel extraction process on the physico-chemical and antioxidant compounds of defatted flours from $R$. heudelotti was assessed.

\section{Materials and Methods}

\subsection{Materials Chemicals and Reagents}

All chemicals and reagents from Sigma Chemical Co. (St. Louis, MO, USA) were of analytical grade. Ultra-pure water of $18.2 \mathrm{M} \Omega$ resistivity was prepared by ELGA water purification system (Flex III, Buckinghamshire, UK) and used in all experiments.

\subsection{Sampling and Sample Preparation}

The plant material was mainly the kernels of $R$. heudilotii (Figure 1). Thus, fresh R. heudilotii kernels were collected from six different producing areas of Cote d'Ivoire (West Africa): Bondoukou, Agboville1, Agboville2, Divo, Lakota, and Vavoua. The unit operations involved in each method of kernels extraction processes are shown in Figure 2. After collection, samples $(n=6)$ were immediately transferred to the Food Biochemical and Tropical Products Technology Laboratory (Abidjan, Cote d'Ivoire) for preparation of the defatted flour. Upon arrival, the kernels were cleaned manually to remove all foreign materials and dried in an oven at $40{ }^{\circ} \mathrm{C}$ for $24 \mathrm{~h}$ prior to analysis. The dried matter was ground into fine flour using a laboratory blender (Bimby mod. 2200, Vorwerk, Wuppertal, Germany). Fine flour obtained was defatted for $12 \mathrm{~h}$ with hexane using Soxhlet apparatus [14]. All analyses were carried out in three repetitions on equal amounts of samples. 

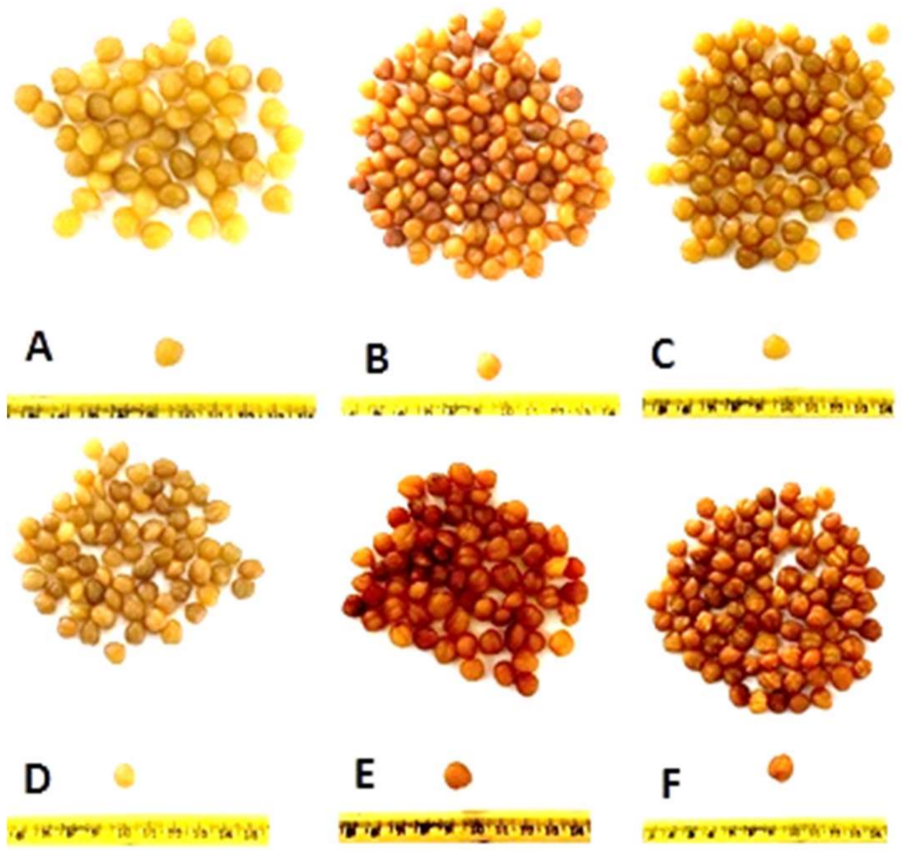

Figure 1. Ricinodendron heudelotii seed kernel samples from "Bondoukou" (A), "Agboville2" (B), “Divo" (C), “Lakota” (D), “Vavoua" (E) and “Agboville1” (F).

\subsection{Proximate Analysis of Defatted Flours from R. heudelotti Seeds Kernels}

The methods used for sample treatment and analysis (Moisture, ash, protein) were carried out following standard procedures recommended by Association of Official Analytical Chemists (AOAC) [14]. Moisture was determined by gravimetric method and was heated in an oven at $105 \pm 1{ }^{\circ} \mathrm{C}$ until it became a constant mass. Total nitrogen was determined by the Kjeldahl method and converted into protein using factor 6.25. Ash was determined by gravimetry of incinerated sample, in muffle, at $550{ }^{\circ} \mathrm{C}$. The total carbohydrates (TCHO) were calculated by difference as suggested by Food and Agriculture Organization/World Health Organization (FAO/WHO) procedure [15]. The total dietary fiber content was determined following Prosky's protocol [16]. Total sugars (TS) were determined using the phenol-sulphuric acid method [17], while the reducing sugars (RS) were quantified by the oxido-reduction method using 3.5-dinitrosalysislic acid (DNS) as oxidizing agent [18]. The energy content was estimated by multiplying each gram of carbohydrate, protein, and lipid by $4 \mathrm{kcal}, 4 \mathrm{kcal}$, and $9 \mathrm{kcal}$, respectively [19].

\subsection{Mineral Composition of Defatted Flours from R. heudelotti Seeds Kernels}

The sample was accurately weighted and dry-ashed $\left(550^{\circ} \mathrm{C}\right.$, one night; method 40-70.01) [20] in a muffle furnace (Cavallo Srl, Buccinasco, Italy). Grey ashes were treated with high purity hydrogen peroxide $\left(\mathrm{H}_{2} \mathrm{O}_{2} 30 \%\right.$ Suprapur, St. Louis, MO, USA) to obtain white ashes, which were dissolved with acid solution (2 $\mathrm{mL} \mathrm{HCl} \mathrm{30 \%} \mathrm{Suprapur,} \mathrm{St.} \mathrm{Louis,} \mathrm{MO,} \mathrm{USA)} \mathrm{and} \mathrm{diluted} \mathrm{with} \mathrm{distilled} \mathrm{water}$ in volumetric flasks. Mineral concentrations (potassium $(\mathrm{K})$, magnesium $(\mathrm{Mg})$, iron $(\mathrm{Fe})$, calcium $(\mathrm{Ca})$, and zinc $(\mathrm{Zn})$ ) were determined by Atomic Absorption Spectroscopy (Analyst 800 Perkin Elmer, Waltham, MA, USA), while phosphorous $(\mathrm{P})$ and chlorine $(\mathrm{Cl})$ were determined by a colorimetric method using Cary 3E UV-VIS Spectrophotometer (Varian, Mulgrave, Australia) [21]. All analyses were performed in triplicate with two measurements per analysis. All minerals were reported as $\%$ dry weight. 


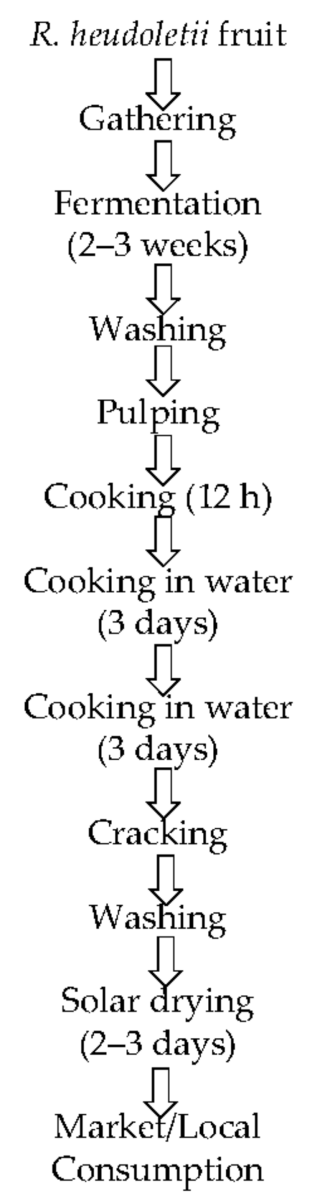

(A)

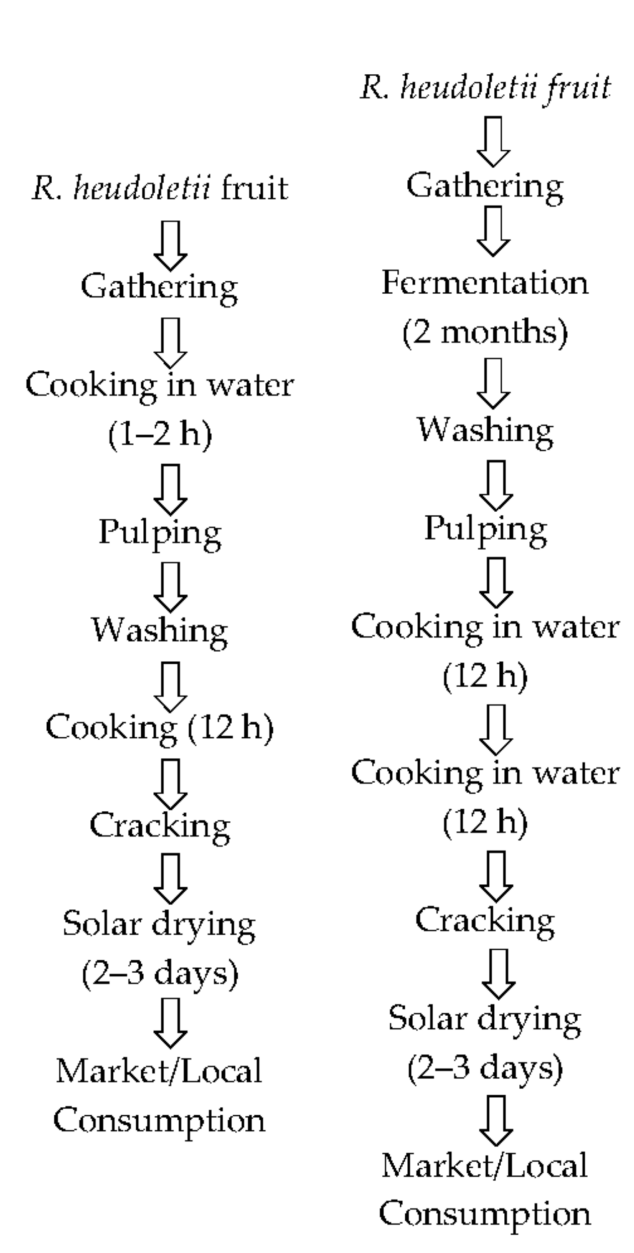

(B)
R. heudoletii fruit

Gathering

Cooking in water

(12 h)

?

Cooking in water

$(12 \mathrm{~h})$
Cracking
Market/Local
Consumption

(D)

R. heudoletii fruit
Gathering

(E)
(F)

Figure 2. Flow diagram of the process of harvesting of seeds and kernels extraction from $R$. heudelotii fruit from six producing areas of Cote d'Ivoire: Bondoukou (A), Agboville2 (B), Divo (C), Lakota (D), Vavoua (E), and Agboville1 (F). 


\section{5. $p H$ Determination of Defatted Flours from R. heudelotti Seeds Kernels}

The $\mathrm{pH}$ of samples was measured by use of a pH meter, model 744 (Metrohm AG, Herisau, Switzerland) following to the procedure of the Swiss Food Manual (Schweizerisches Lebensmittel-Buch, 2001). The $\mathrm{pH}$ meter was calibrated with standard buffers 4 and 7 , before the $\mathrm{pH}$ was measured. The results are expressed in $\mathrm{pH}$ units and are read directly on the $\mathrm{pH}$ meter dial.

\subsection{Total Titrable Acidity (TTA) of Defatted Flours from R. heudelotti Seeds Kernels}

The acidity of kernels was determined by titration following the method described by AOAC [14] using phenolphthalein (Sigma-Aldrich Chemical Co., St. Louis, MO, USA) as an indicator. The acidity of the samples was calculated by using the following equation.

$$
\text { Titrable acidity }(\%)=0.0090 \times \text { volume of } \mathrm{NaOH} \text { used } / 100,
$$

\subsection{Phytochemical Analysis of Defatted Flours from R. heudelotti Seeds Kernels}

\subsubsection{Total Flavonoids Determination}

The flavonoid assay was performed according to the method described by Meda et al. [22]. Briefly, a distilled water $(5.6 \mathrm{~mL})$ was added to $1 \mathrm{~mL}$ of defatted kernels flours of $R$. heudelotti extracts. Then, $3 \mathrm{~mL} 95 \%$ ethanol $(v / v)$ was added, followed by $10 \%$ aluminium chloride solution $(0.2 \mathrm{~mL})$ and $0.2 \mathrm{~mL}$ of $1 \mathrm{~mol} / \mathrm{L}$ potassium acetate. In a like manner, the amount of $10 \%(\mathrm{~m} / \mathrm{V})$ aluminum chloride was substituted by the same amount of distilled water in the blank. For assay of flavonoids, the absorbance was measured at $415 \mathrm{~nm}$ using a UV-VIS spectrophotometer (Cary 50 Bio, Varian Australia Pty. Ltd., Victoria, Australia) after incubation at room temperature for $30 \mathrm{~min}$. A standard range established from a stock solution of quercetin $(0.1 \mathrm{mg} / \mathrm{mL})$ under the same conditions as the test determines the amount of flavonoids in the sample. Thus, flavonoids in defatted flours from $R$. heudelotti extracts were expressed as mg quercetin equivalents per gram of dried sample (mg QE/g).

\subsubsection{Phytic Acid Content}

Phytic acid was determined by the New Chromophore method of Mohammed et al. [23]. Briefly, a mass of $0.5 \mathrm{~g}$ of the sample is homogenized in $25 \mathrm{~mL}$ of $3 \%$ trichloroacetic acid (TCA) for $45 \mathrm{~min}$ and then centrifuged at $3500 \mathrm{rpm}$ for $15 \mathrm{~min}$. To $5 \mathrm{~mL}$ of the supernatant obtained are added $3 \mathrm{~mL}$ of $1 \%$ iron chloride prepared in hydrochloric acid $\mathrm{HCl}(1 \mathrm{M})$, which is then heated in a water bath for $45 \mathrm{~min}$. After cooling the mixture, $5 \mathrm{~mL}$ of hydrochloric acid $(\mathrm{HCl})$ is added and the mixture is then left to stand for $2 \mathrm{~h} .5 \mathrm{~mL}$ of $1.5 \mathrm{M}$ sodium hydroxide is then added to the mixture obtained above; the whole is carried in a water bath for $15 \mathrm{~min}$ and centrifuged again at $3500 \mathrm{rpm}$ for $15 \mathrm{~min}$ after cooling. One milliliter of the supernatant is removed, to which is added $4.5 \mathrm{~mL}$ of distilled water and $4.5 \mathrm{~mL}$ of ortho-phenanthroline reagent. The optical density is read at $470 \mathrm{~nm}$ on the spectrophotometer against a blank. A reference range was established from a stock solution of Mohr salt (iron $10 \mu \mathrm{g}$ iron $/ \mathrm{mL}$ ) under the same testing conditions as those for determining the amount of ferric phytate-sample. The amount of phytate content was expressed as $\mathrm{mg} / 100 \mathrm{~g}$ dry weight.

\subsubsection{Tannins}

The estimation of the extracted tannins was carried out according to the method described by Bainbridge et al. [24]. To determine tannins in defatted flours from Ricinodendron heudelotti, two grams of sample with $30 \mathrm{~mL}$ of $80 \%$ acetone were mixed in $50 \mathrm{~mL}$ Erlen-meyer flasks. The mixture was shaken for $15 \mathrm{~min}$ and filtered under pressure through a sintered glass using a Buchner. Acetone was then removed by evaporation using a rotary evaporator (Buchi Rotavapor R-124, Buchi Labortechnik, Flawil, Switzerland). The extracts obtained were diluted 20 times with distilled water. $1 \mathrm{~mL}$ of diluted extract was introduced into test tubes covered beforehand with aluminum foil to exclude the light, 
follow-up of $3 \mathrm{~mL}$ of a coldly prepared vanillin $4 \%$ solution in the ethanol $(p / v)$. Each test tube is agitated and $1 \mathrm{~mL}$ of concentrated $\mathrm{HCl}$ was added in each tube which thereafter was left at rest at room temperature for $15 \mathrm{~min}$. Thereafter, the absorbency was measured photometrically (Spectrophotometer T80 + UV/Vis Spectrometer, PG Instruments Ltd, Leicestershire, United Kingdom) at the wavelength of maximum absorption of $500 \mathrm{~nm}$ against a blank solution (without extract). Catechin was used as a reference standard. Tannins content of samples was estimated using a calibration curve for $(+)$-catechin. The results obtained were expressed as $\mathrm{mg}$ catechin equivalent/g of sample, on a dry weight basis.

\subsubsection{Oxalates}

The method described by Day and Underwood [25] was used to determine the oxalate content of defatted kernels flours of $R$. heudelotti extracts. This method consists of extracting the total oxalates (insoluble and soluble) followed by titrimetric analysis. Briefly, one gram of dried powdered and $75 \mathrm{~mL}$ of $1.5 \mathrm{~N} \mathrm{H}_{2} \mathrm{SO}_{4}$ were added in $100 \mathrm{~mL}$ conical flask. The mixture was carefully shaken on a mechanical shaker for $1 \mathrm{~h}$. Then, the solution was filtered using Whattman No.1 filter paper. A $25 \mathrm{~mL}$ of filtrate was titrated hot $\left(80-90^{\circ} \mathrm{C}\right.$ ) with freshly prepared $0.1 \mathrm{~N} \mathrm{KMnO}_{4}$ solution until the colour of the solution become pink persisted for 30 seconds. The results were expressed as $\mathrm{mg} / 100 \mathrm{~g}$ dry weight.

\subsubsection{Total Phenolic Assay}

The phenolic extracts of defatted kernel flours of $R$. heudelotti were obtained following the procedure described by N'dri et al. [26] and quantified using the Folin-Ciocalteu assay [27]. Briefly, $10 \mathrm{~mL}$ of crude extract and 10-fold diluted Folin-Ciocalteau reagent were reacted with sodium carbonate at a concentration of $6 \%(w / v)$ into $25 \mathrm{~mL}$ of volumetric flask containing deionized water. Following a mean incubation period of $15 \mathrm{~min}$ and away from light, the mixture's absorbance against the reagent blank (the blank being prepared under the same conditions as before but without extract) was measured at $725 \mathrm{~nm}$ using a spectrophotometer (model T80 x UVNIS Spectrometer PG Instruments. Ltd, Leicestershire, United Kingdom). Total phenolic content was presented as mg gallic acid equivalent (GAE)/100 g sample.

\subsection{Statistical Analyses}

The collected data were subjected to a statistical analysis carried out with the Statistica 9.0 software (StatSoft, Krakow, Poland). They were presented as standard deviation means (SD) and analyzed by Excel 2013 from Microsoft Corporation. The differences between the samples were revealed by analysis of variance (ANOVA). Duncan's multiple range test $(p<0.05)$ was used to determine the significances within treatments. The similarity between extraction systems of the seeds kernels were examined by multidimensional scaling (MDS). In order to do so, it took a proximity matrix between each pair of samples in the set of chemical constituents. Proximity indicate similarity estimates (similar objects) or rather the opposite (different objects) and are simple Euclidean distances applied to the standardized data. One-way ANOVA test with Duncan's multiple range post hoc was used to compare similarity groups with significant differences among them when $p \leq 0.05$. All analyses were performed in duplicate or triplicate.

\section{Results and Discussion}

In this study, the effect of kernels extraction methods on chemical composition and antioxidant activity of defatted flours from $R$. heudelott $i$ kernels were assessed.

Firstly, we performed a nutritional characterization of defatted flour samples from $R$. heudelotii, differentiating them according to the site of production. The findings were presented in Table 1. Overall, there were significant differences $(p<0.05)$ between the defatted kernel flour samples for all the parameters studied, a result that could be attributed to their steps of preparation (post-harvest traditional technologies) and to the environmental condition. Proximate composition confirms that the defatted kernel flours from $R$. heudelotii have potentially high protein content to satisfy the protein 
demand of the populations and animal foods. They contain a considerable number of proteins, which vary from $47.0 \%$ (Akpi-Vav) to 61.3\% (Akpi-Lak), which is higher than protein rich foods such as quinoa [28], bambara groundnut [29], and cowpeas [30] seeds which range between 13.5 and $26.8 \%$. Considering the same sample, defatted kernel flours from $R$. heudelotii are twice as rich in protein compared with almonds (22.4-24.9\%) found in the work of Saki et al. [5] and would cover the protein needs of populations, especially in developing countries. The high concentration of protein can be attributed to the water loss and dry matter concentration after cooking, drying, and defatting kernels of $R$. heudelotti. The protein contents of samples obtained from Bondoukou (Akpi-Bon: 56.6\%), Agboville1 (Akpi-Agb1: 57.0\%), and Lakota (Akpi-Lak: 61.3\%) sites were higher compared to 50.3\% obtained by Tchiegang et al. [31], but those obtained at Agboville2 (Akpi-Agb2: 49.4\%), Divo (Akpi-Div: 48.8\%), and Vavoua (Akpi-Vav: 47.0\%) were approximately similar. The intrinsic differences between proteins (Table 1) may be explained by the compositional changes following the degradation of other constituents during the cooking processes [32]. Indeed, according to Fabbrin [33], heating before cooking improves the nutritional value and the availability of nutrients, which could be the case in this study. Total carbohydrates (as calculated by difference) was moderate (20.5-37.8\%).

Table 1. Proximate composition, energy, and $\mathrm{pH}$ values of defatted flours from $\mathrm{R}$. heudelott $i$ seeds kernels.

\begin{tabular}{|c|c|c|c|c|c|c|}
\hline \multirow[b]{2}{*}{ Composition } & \multicolumn{6}{|c|}{ Defatted Kernel Flour Samples } \\
\hline & Akpi-Agb1 & Akpi-Agb2 & Akpi-Div & Akpi-Lak & Akpi-Bon & Akpi-Vav \\
\hline Dry matter (\%) & $94.3 \pm 0.0^{\mathrm{a}}$ & $92.7 \pm 0.0^{\mathrm{b}}$ & $95.6 \pm 0.0^{c}$ & $94.0 \pm 0.0^{\mathrm{a}, \mathrm{b}}$ & $93.7 \pm 0.0^{\mathrm{d}}$ & $95.0 \pm 0.0^{\mathrm{e}}$ \\
\hline TS $(\%)$ & $7.8 \pm 0.8^{\mathrm{a}}$ & $9.8 \pm 0.1^{\mathrm{a}}$ & $12.9 \pm 0.1^{\mathrm{a}}$ & $17.1 \pm 0.2^{\mathrm{a}}$ & $13.6 \pm 0.1^{\mathrm{a}}$ & $7.3 \pm 0.6^{\mathrm{a}}$ \\
\hline RS (\%) & $0.2 \pm 0.0^{\mathrm{a}}$ & $0.3 \pm 0.0^{\mathrm{a}}$ & $0.3 \pm 0.0^{\mathrm{a}}$ & $0.2 \pm 0.0^{\mathrm{a}}$ & $0.2 \pm 0.0^{\mathrm{a}}$ & $0.2 \pm 0.0^{\mathrm{a}}$ \\
\hline Ash (\%) & $12.5 \pm 0.1^{a, b, c}$ & $12.8 \pm 0.1^{b, c}$ & $13.1 \pm 0.0^{\mathrm{c}}$ & $12.0 \pm 0.1^{\mathrm{a}}$ & $12.2 \pm 0.0^{\mathrm{a}, \mathrm{b}}$ & $11.2 \pm 0.1^{\mathrm{d}}$ \\
\hline Protein $(\%)$ & $57.0 \pm 0.0^{\mathrm{a}}$ & $49.4 \pm 0.1^{b}$ & $48.8 \pm 0.1^{b}$ & $61.3 \pm 0.1^{\mathrm{c}}$ & $56.6 \pm 0.1^{\mathrm{a}}$ & $47.0 \pm 0.0^{\mathrm{d}}$ \\
\hline ТCHO (\%) & $24.7 \pm 0.1^{\mathrm{a}}$ & $31.1 \pm 0.8^{b}$ & $33.8 \pm 0.1^{\mathrm{c}}$ & $20.5 \pm 0.0^{\mathrm{d}}$ & $24.9 \pm 0.1^{\mathrm{a}}$ & $37.8 \pm 0.1^{\mathrm{e}}$ \\
\hline Crude fibre (\%) & $10.0 \pm 0.1^{\mathrm{a}}$ & $13.7 \pm 0.0^{b}$ & $12.5 \pm 0.0^{\mathrm{c}}$ & $11.1 \pm 0.0^{\mathrm{d}}$ & $14.4 \pm 0.0^{\mathrm{e}}$ & $9.5 \pm 0.0^{\mathrm{f}}$ \\
\hline $\mathrm{pH}$ & $6.2 \pm 0.0^{\mathrm{a}}$ & $6.1 \pm 0.0^{\mathrm{b}}$ & $6.7 \pm 0.0^{c}$ & $6.5 \pm 0.0^{\mathrm{d}}$ & $7.1 \pm 0.0^{\mathrm{e}}$ & $6.8 \pm 0.0^{\mathrm{f}}$ \\
\hline TTA (meq/100 g) & $4.3 \pm 0.0^{\mathrm{a}}$ & $4.5 \pm 0.0^{\mathrm{b}}$ & $2.3 \pm 0.0^{\mathrm{c}}$ & $3.1 \pm 0.0^{\mathrm{d}}$ & $1.9 \pm 0.0^{\mathrm{e}}$ & $2.4 \pm 0.0^{\mathrm{c}}$ \\
\hline Energy (kcal/100g) & $326.9 \pm 0.4^{\mathrm{a}}$ & $322.0 \pm 0.2^{b}$ & $330.4 \pm 0.1^{c}$ & $327.4 \pm 0.3^{\mathrm{a}}$ & $325.9 \pm 0.2^{\mathrm{a}}$ & $339.2 \pm 0.2^{d}$ \\
\hline \multicolumn{7}{|c|}{$\begin{array}{l}\text { Data are represented as Means } \pm \mathrm{SD}(n=3) . \quad(\mathrm{a}, \mathrm{b}, \mathrm{c}, \mathrm{d}, \mathrm{e}, \mathrm{f}) \text { Means in the lines with no common } \\
\text { superscript differ significantly }(p<0.05) \text { according to Duncan's test.; Total sugars: TS. RS: reducing } \\
\text { sugars. Total carbohydrates: TCHO. TTA: Total Titratable Acidity. Akpi-Lak = Akpi of Lakota; } \\
\text { Akpi-Bon = Akpi of Bondoukou; Akpi-Agb1=Akpi of Agboville1; Akpi-Agb2 = Akpi of Agoville2; } \\
\text { Akpi-Vav = Akpi of Vavoua; Akpi-Div = Akpi of Divo. }\end{array}$} \\
\hline
\end{tabular}

The carbohydrate total assessed in our samples is almost double when compared to that observed in other seed kernels of $R$. heudelotti seed that come from seven different departments in Cote d'Ivoire [5], but appears lower than that reported for legumes such as bean, chickpea, etc. With low amounts of total sugar (7.3-17.1\%), reducing sugars of samples are yet very low $(0.2-0.3 \%)$, irrespective of the production areas. Similar levels of sugar were observed in defatted flours of $R$. heudelotii collected by Mezajoug and Tchiégang [6]. It was not surprising since several previous studies have shown that the R. heudelotti seeds are naturally known for being very poor in carbohydrate [5]. On the other hand, both carbohydrates and protein results thus give us an indication that the energy source is largely carbohydrate and to some extent protein (through deamination). As for the fibre contents, our results were significantly higher than those of seed kernels of $R$. heudelotti (2.3-2.5\%) from seven different departments in Cote d'Ivoire [5]. These results were similar to studies of Mezajoug and Tchegang [6], Mezajoug et al. [34], and Tchiegang et al. [31], who also found 11.0\%, 10.9\%, and 13.9\%, respectively. Vavoua was the region with the lowest value (Akpi-Vav: 9.5\%), but the value of 14.4\% (Akpi-Bon) obtained from Bondoukou is slightly lower than the fiber content of the Pistachios from Bronte in Italy (15.5\%) that are considered by D'Evoli et al. [35] as a key component of a healthy dietary pattern. Defatted flours from $R$. heudelotii seed kernels could therefore be considered as a valuable source of dietary fiber and, by inference, a good source of cellulose. From a nutritional 
point of view, the range of fiber content recorded is advantageous, as fiber in food is essential to decreasing cholesterol and blood sugar. It has a high water-holding capacity during their passage through the digestive tract and constitutes roughage, facilitating gastrointestinal transit by reducing the transit time [36]. The calculated metabolizable energy values of defatted flours of $R$. heudelotti seed kernels presented in Table 1 ranged from $327.4 \mathrm{kcal} / 100 \mathrm{~g}$ (Akpi-Lak) to $339.2 \mathrm{kcal} / 100 \mathrm{~g}$ (Akpi-Vav). These values are close to those of biscuits made from compound flours (wheat flour + precooked taro meal $+R$. heudelotii oilcake) by Fombang et al. [37] with incorporation rates ranging from 0 to $35 \%$ of $R$. heudelotii oilcake. The differences observed in these samples could be due to the difference in protein and carbohydrate reported in proximate composition. Indeed, both carbohydrate (20.5-37.8\%) and protein level (47.0-61.3\%) were the highest contributors to calories from the determination of energy produced. Dry matter content of defatted kernels flours was found to vary between $92.3 \%$ and $95.6 \%$ of the fresh weight. These values are similar to those of Mezajoug [38]. Otherwise, the variation of dry matter implies that of water content in the samples. Low moisture content in foods limits microbial activities, while high moisture contents in food enhances microbial growth and hence food spoilage [39]. Thus, the low moisture content observed in this study (4.4-6.7\%) is a desirable phenomenon. Another important aspect of the report is the statement that the lowest dry matter content (Akpi-Agb2: 92.3\%, Akpi-Bon: 93.7\%, Akpi-Div: 94.0\%) had kernels that had undergone a very long cooking time, especially through pre-cooking and then cooking. This shows that, the longer the cooking time, the less the dry matter [38]. In contrast, dry matter content in Divo sample (Akpi-Div: 97.3\%) would have increased with a relatively short cooking time and pre-cooking on a low heat. Thus, the long duration and the severity of cooking of $R$. heudelotti seeds certainly increased the absorption of water during cooking. Certainly, defatted flours from $R$. heudelotti seeds kernels are suitable for long-term storage, but each of them will not have the same shelf life. The ash content of samples ranged from 11.2\% (Akpi-Vav) to 13.1\% (Akpi-Div). These levels vary from one process to another and are high with ash values of $3.68 \%, 3.22 \%$, and 3.56\% reported for pigeon pea, lima bean, and lablab bean, respectively [40]. Ash content is an indicator for mineral elements [41]. Thus, from the result, it could be seen that Akpi-Div sample with 13.1\% was the best in terms of mineral content. The minor ash variation could be due to the geographical origin of the samples, the climatic conditions, and the edaphic characteristics of soils [42]. Pomeranz and Clifto [43] recommends 1.5 to $3.5 \%$ of ash content in the seeds for animal feeds and human consumption. In this study, the ash content falls within this range, hence it can be recommended. For all samples, $\mathrm{pH}$ was slightly acid (6.1 to 7.1), while total acidity was low (1.9 to $4.5 \mathrm{meq} / 100 \mathrm{~g}$ ). These values were close to that of rapeseed meal ( $\mathrm{pH} 6.4$ ) founded by Mayombo et al. [44]. The observed difference in the results may be related to the storage process, which is a function of the drying step [45]. Total acidity in the samples is consistent with the observations of Treche et al. [45]. These authors reported values between 2.9 and $4.6 \mathrm{mmol} / \mathrm{MS} 100 \mathrm{~g}$ in cassava flour in Congo (Central Africa) according to traditional processes of treatment of the tubers. The observed difference in titrable acidity is due to the drying time. For Treche et al. [45], the drying time has a significant influence on the acidity of the flour. A long drying time would reduce the titrable acidity of the flours. The determinations of titrable acidity, $\mathrm{pH}$, and oxalic acid are of interest because of their alleged adverse effect on mineral bioavailability.

Secondly, we evaluated some minerals of defatted flours of $R$. heudelotii in order to assess the nutritional quality of the ash fraction. Minerals are essential nutrients and may help many body metabolic functions. Table 2 shows the concentration of mineral elements of defatted kernels flours of $R$. heudelotii for the various locations. Overall, the mineral and trace element contents differed significantly between samples. The mineral content of plants varies, generally, from soil types, whether fertilizer is ingested or not [46]. The results showed that defatted kernel flours of $R$. heudelotti are a good source of dietary minerals. Among the microelements, the predominant minerals were magnesium $(12.0-40.0 \%)$. The seed kernel samples of $R$. heudelotti collected in six producing areas of Cote d'Ivoire were found to be the richest in phosphorus $(0.3-2.0 \%)$, calcium $(0.3-0.6 \%)$, and potassium $(0.1-0.4 \%)$, while iron contents $(2.0-3.0 \%)$ were similar among the samples. The magnesium content found revealed 
significant variability with respect to traditional extraction process. The content in the samples could be related to the longer or shorter cooking time [38]. In our samples, the magnesium content was similar to the amounts found in the soya flours [47]. Phosphorus (P) levels, present in small amounts in samples, are lower than phosphorus content in rapeseed meal [44]. These low contents are thought to be related to phytate-iron-phosphorus complex formation [44], especially in the pre-cooking and cooking steps, which influence the mineral content by duration and intensity. Minerals: calcium (Ca) and potassium (K) represent the lowest levels in defatted kernels flours from $R$. heudelotti. Calcium contents are significantly lower than those in rapeseed meal $(830 \mathrm{mg} / 10 \mathrm{~g})$ and soybean meal $(340 \mathrm{mg} / 100 \mathrm{~g})$ obtained by Sauvant et al. [48], while potassium contents are also lower than those revealed in oilcakes of the same matrix in Cameroon [38]. Variations in calcium content could be due to calcium intake or not from cooking water through the crack in the hull. According to Lestradet and Machinot [49], boiling heavily increases the calcium intake during cooking. The magnitude of the difference depends on the temperature and the duration of treatment. It should be noted that chlorine and zinc were not detected in our samples.

Table 2. Mineral composition of defatted flours from $R$. heudelotti seeds kernels.

\begin{tabular}{cccccccc}
\hline \multicolumn{7}{c}{ Mineral Elements } \\
\hline $\begin{array}{c}\text { Defatted } \\
\text { Kernel Flour }\end{array}$ & $\mathbf{M g}(\%)$ & $\mathbf{P ~ ( \% )}$ & $\mathbf{C a}(\%)$ & $\mathbf{K}(\%)$ & Fe (\%) & Zn (\%) & $\mathbf{C l}(\%)$ \\
\hline Akpi-Agb1 & $19.0 \pm 0.0^{\mathrm{a}, \mathrm{b}}$ & $2.0 \pm 0.0^{\mathrm{a}}$ & $0.6 \pm 0.0^{\mathrm{a}}$ & $0.2 \pm 0.0^{\mathrm{a}, \mathrm{b}}$ & $3.0 \pm 0.0^{\mathrm{b}}$ & n.d. & n.d. \\
Akpi-Agb2 & $30.0 \pm 0.0^{\mathrm{b}}$ & $1.0 \pm 0.0^{\mathrm{a}}$ & $0.5 \pm 0.0^{\mathrm{b}}$ & $0.3 \pm 0.0^{\mathrm{c}}$ & $2.0 \pm 0.0^{\mathrm{a}}$ & n.d. & n.d. \\
Akpi-Div & $20.0^{\mathrm{a}} \pm 0.0^{\mathrm{a}, \mathrm{b}}$ & $0.4 \pm 0.0^{\mathrm{b}}$ & $0.4 \pm 0.0^{\mathrm{c}, \mathrm{d}}$ & $0.1 \pm 0.0^{\mathrm{a}}$ & $2.1 \pm 0.0^{\mathrm{a}}$ & n.d. & n.d. \\
Akpi-Lak & $12.0 \pm 0.0^{\mathrm{a}}$ & $0.3 \pm 0.0^{\mathrm{b}}$ & $0.3 \pm 0.0^{\mathrm{c}}$ & $0.2 \pm 0.0^{\mathrm{a}, \mathrm{b}}$ & $2.0 \pm 0.0^{\mathrm{a}}$ & n.d. & n.d. \\
Akpi-Bon & $30.0 \pm 0.0^{\mathrm{a}, \mathrm{b}}$ & $0.4 \pm 0.0^{\mathrm{c}}$ & $0.4 \pm 0.0^{\mathrm{d}}$ & $0.4 \pm 0.0^{\mathrm{d}}$ & $2.1 \pm 0.0^{\mathrm{a}}$ & n.d. & n.d. \\
Akpi-Vav & $40.0 \pm 0.0^{\mathrm{c}}$ & $1.0 \pm 0.0^{\mathrm{a}}$ & $0.6 \pm 0.0^{\mathrm{a}, \mathrm{b}}$ & $0.2 \pm 0.0^{\mathrm{a}, \mathrm{b}}$ & $2.3 \pm 0.0^{\mathrm{a}}$ & n.d. & n.d. \\
\hline
\end{tabular}

Data are represented as Means $\pm \mathrm{SD}(n=3)$. $\left({ }^{\mathrm{a}, \mathrm{b}, \mathrm{c}}\right)$ Means in the lines with no common superscript differ significantly $(p<0.05)$ according to Duncan's test. Akpi-Lak = Akpi of Lakota; Akpi-Bon = Akpi of Bondoukou; Akpi-Agb1 = Akpi of Agboville1; Akpi-Agb2 = Akpi of Agoville2; Akpi-Vav = Akpi of Vavoua; Akpi-Div = Akpi of Divo; K: Potassium; P: Phosphorus; Ca: Calcium; Mg: Magnesium; Fe: Iron; Zn: Zinc; Cl: Chlorine. n.d.: no detected

The trace elements levels (iron) detected in kernels were moderate compared to the values ( 8 and $6 \mathrm{mg} /$ day, respectively) recommended for human dietary allowance [50]. In this study, the extraction process methods of $R$. heudilotii seeds kernels did not considerably affect the determination of iron produced.

Finally, we evaluated some of the nutritive and antioxidant compounds of defatted flours from $R$. heudelotti kernels (Table 3). The result of the analysis revealed an appreciable amount of total polyphenols, phytates, flavonoids, tannins, and oxalates. Noticeable differences were observed between samples for all the components measured $(p<0.05)$ with the exception of oxalates and phytates. Indeed, there was high variability with respect to traditional extraction process. The polyphenols are the main dietary antioxidants among selected $R$. heudilotii seeds kernels. In our samples, the total polyphenols content ranges from $216.6 \mathrm{mg} / 100 \mathrm{~g}$ (Akpi-Bon) to $403.9 \mathrm{mg} / 100 \mathrm{~g}$ (Akpi-Agb1) and was low when compared to defatted flours from $R$. heudelotti kernels collected in local food spice market in Mbalmayo, Cameroon (940.00 mg/100 g). On the other hand, these amounts are higher than those found in the defatted flours particles fractions: $>500 \mu \mathrm{m}(170.01 \mathrm{mg} / 100 \mathrm{~g}), 400-500 \mu \mathrm{m}$ $(210.0 \mathrm{mg} / 100 \mathrm{~g})$, and $<160 \mu \mathrm{m}(80.05 \mathrm{mg} / 100 \mathrm{~g})$ of $R$. heudelotti kernels [6]. Following the example of previous studies that tested fruits from tropical regions for their polyphenol contents [51], all defatted flours samples of $R$. heudilotii evaluated in this study can be categorized as having a low concentration of phenolic compounds ( $<500 \mathrm{mg} / 100 \mathrm{~g}$ ); consequently, they are a low source of phenolic compounds. As postulated by Mehinagic et al. [52], the total polyphenol content depends not only on the extrinsic factors (geographical and climatic factors) but also the genetic factors, the degree of maturation of the plant, storage time, and the technical route have strong influence on the content of 
polyphenols. Compared to the amounts found by Odinga et al. [53], the concentration of flavonoids was high but lower compared to the amounts found in soya [54]. Defatted flours from R. heudelotti kernels collected in Vavoua $(4.6 \mathrm{mg} / 100 \mathrm{~g}$ ) had the highest levels of flavenoids followed by those collected in Divo (3.1 mg/100 g), Agboville2 (2.7 mg/100 g), Agboville1 (1.8 mg/100 g), Bondoukou $(1.1 \mathrm{mg} / 100 \mathrm{~g})$, and Lakota $(1.0 \mathrm{mg} / 100 \mathrm{~g})$ in that order. These differences can be explained as not only due to differences in producing areas of the samples but also due to the seeds kernels extraction systems applied. This fact was also found by Bolanho and Beléia [54]. It is now common knowledge that various post-harvest traditional technologies can reduce and/or destroy several nutritional factors [55]. Flavonoids have a varied biological activity, which includes their ability to eliminate biological radicals and superoxide anions radicals. Flavonoids therapy can also be used in the treatment of some disorders due to its anti-inflammatory, anti-angionic, and anti -allergic effects, as well as its analgesic and antioxidant properties [56]. On the other hand, it has been observed that the defatted flours from $R$. heudelotti kernels used in this study contained anti- nutrients, with values ranging from $714.7 \mathrm{mg} / 100 \mathrm{~g}$ (Akpi-Vav) to $972.9 \mathrm{mg} / 100 \mathrm{~g}$ (Akpi-Agb1) for oxalates, 16.4 (Akpi-Agb1) to $41.8 \mathrm{mg} / 100 \mathrm{~g}$ (Akpi-Lak) for tannins, and 52.2 (Akpi-Div) to 71.4 (Akpi-Vav) for phytates.

Table 3. Bioactive compounds content of defatted flours from $R$. heudelotti seeds kernels.

\begin{tabular}{|c|c|c|c|c|c|}
\hline \multirow[b]{2}{*}{$\begin{array}{c}\text { Defatted } \\
\text { Kernel Flour }\end{array}$} & \multicolumn{5}{|c|}{ Bioactive Compounds } \\
\hline & $\begin{array}{l}\text { Polyphenols } \\
\text { (mg/100g) }\end{array}$ & $\begin{array}{l}\text { Phytates } \\
\text { (mg/100g) }\end{array}$ & $\begin{array}{c}\text { Flavonoids } \\
\text { (mg/100g) }\end{array}$ & $\begin{array}{l}\text { Tannins } \\
\text { (mg/100g) }\end{array}$ & $\begin{array}{l}\text { Oxalate } \\
\text { (mg/100g) }\end{array}$ \\
\hline Akpi-Agb1 & $403.9 \pm 0.6^{\mathrm{a}}$ & $62.3 \pm 0.1^{\mathrm{a}}$ & $1.8 \pm 0.0^{\mathrm{a}, \mathrm{b}}$ & $16.4 \pm 0.0^{\mathrm{a}}$ & $972.9 \pm 0.0^{\mathrm{a}}$ \\
\hline Akpi-Agb2 & $346.4 \pm 0.1^{\mathrm{a}, \mathrm{b}}$ & $52.3 \pm 0.3^{a}$ & $2.7 \pm 0.0^{\mathrm{a}, \mathrm{b}}$ & $23.9 \pm 0.0^{b}$ & $972.3 \pm 0.0^{\mathrm{a}}$ \\
\hline Akpi-Div & $347.4 \pm 1.2^{\mathrm{a}, \mathrm{b}}$ & $52.2 \pm 0.1^{\mathrm{a}}$ & $3.1 \pm 0.0^{b}$ & $21.8 \pm 0.0^{\mathrm{a}, \mathrm{b}}$ & $973.6 \pm 0.0^{\mathrm{a}}$ \\
\hline Akpi-Lak & $285.2 \pm 0.1^{\mathrm{b}}$ & $61.9 \pm 0.1^{\mathrm{a}}$ & $1.0 \pm 0.0^{\mathrm{a}}$ & $41.8 \pm 0.1^{\mathrm{c}}$ & $881.1 \pm 0.0^{\mathrm{a}}$ \\
\hline Akpi-Bon & $216.6 \pm 0.2^{c}$ & $63.3 \pm 0.0^{\mathrm{a}}$ & $1.1 \pm 0.0^{\mathrm{a}}$ & $18.5 \pm 0.1^{\mathrm{a}, \mathrm{b}}$ & $908.1 \pm 0.0^{\mathrm{a}}$ \\
\hline Akpi-Vav & $348.4 \pm 0.0^{\mathrm{a}, \mathrm{b}}$ & $71.4 \pm 0.1^{\mathrm{a}}$ & $4.6 \pm 0.0^{\mathrm{c}}$ & $22.0 \pm 0.0^{\mathrm{a}, \mathrm{b}}$ & $714.7 \pm 0.0^{\mathrm{a}}$ \\
\hline
\end{tabular}

Data are represented as Means $\pm \mathrm{SD}(n=3)$. $\left({ }^{\mathrm{a}, \mathrm{b}, \mathrm{c}}\right)$ The values within a column with different superscript letters are signifcantly $(p<0.05)$ different according to Duncan's test. Akpi-Lak $=$ Akpi of Lakota; Akpi-Bon = Akpi of Bondoukou; Akpi-Agb1 = Akpi of Agboville1; Akpi-Agb2 = Akpi of Agoville2; Akpi-Vav = Akpi of Vavoua; Akpi-Div = Akpi of Divo.

Their presence in the samples has a deleterious effect in the areas of human nutrition and food production. For example, oxalate is a chelating agent that binds calcium very effectively [41]. As mentioned earlier, the defatted flours from $R$. heudelotti seed kernels are a good source of dietary minerals, although in this study their oxalate and phytate contents were equally high. The oxalate amounts found in the kernel's defatted flour are similar to other plant food rich in oxalate [57] but are distinctly lower compared to the content found by Mezajoug and Tchiégang [6], which presented more than $2000 \mathrm{mg} / 100 \mathrm{~g}$ of oxalates in defatted flours from R. heudelottii seeds kernels. In all cases, it is now known that vegetables-based diets with high oxalate content can lead to an acute loss of metabolic calcium (hypocalcemia) [41]. The phytate amount of defatted flours from $R$. heudelotti kernels is very high compared to 17.0-18.1 mg/100 g found by Mezajoug and Tchiégang [6] for unsieved defatted flours of $R$. heudelotti kernels. The highest concentrations of phytate could be disadvantageous to the health status of consumers. Indeed, phytates are anti-nutrients that chelate divalent cations such as $\mathrm{Zn}^{2+}, \mathrm{Fe}^{2+}, \mathrm{Fe}^{3+}, \mathrm{Ca}^{2+}, \mathrm{Mg}^{2+}, \mathrm{Mn}^{2+}$, and $\mathrm{Cu}^{2+}$, thereby reducing their bioavailability. It is well documented that tannins negatively affect protein digestibility by reducing the bioavailability of iron and calcium intake, as well as carbohydrates, which lowers the energy value of dietary intakes [58]. However, its anti-nutritional effects are a function of their chemical structure and dosage [59]. In the case of our samples, tannin level was found to be high in comparison with tannic acid found in some literatures $[6,38,53]$. The differences between them probably indicate a beneficial effect on total tannin content due to cooking process. This fact is also corroborated by those mentioned by Mezajoug [38]. This author showed that long cooking times (90-120 min) reduced the tannin content 
significantly. Because our sampling is subject to many parameters such as geographical area of production, cultivation cycle, and climatic conditions, consistent interpretations of results may be hindered. Thus, multidimensional scaling (MDS) was applied to the physicochemical parameters for better conclusions.

\section{MDS Applied to Defatted Flours from R. heudelotii Sample Data}

By performing principal coordinate analysis, the MDS plot presented in Figure 3 was obtained.

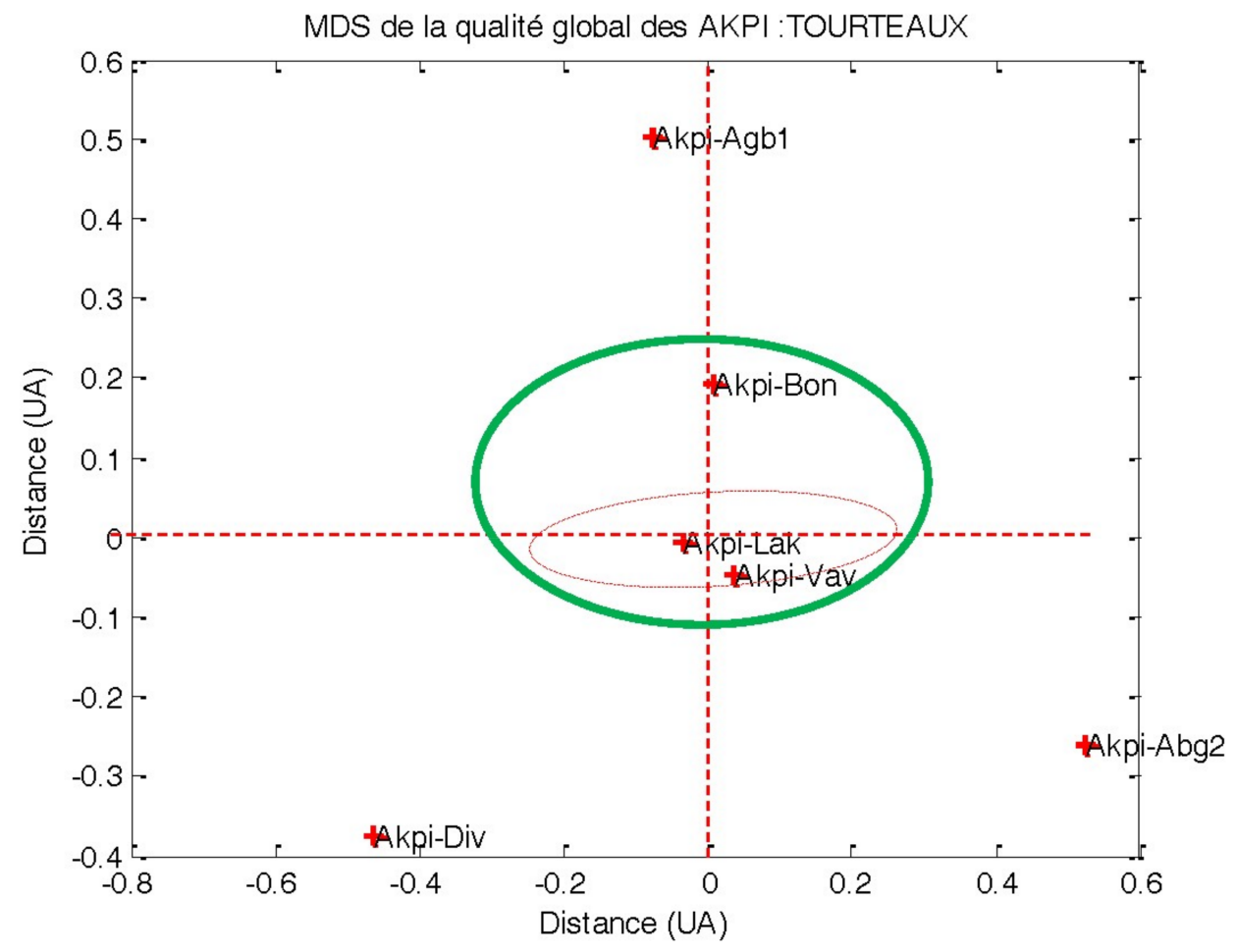

Akpi-Lak = Akpi of Lakota; Akpi-Bon $=$ Akpi of Bondoukou; Akpi-Agb1 $=$ Akpi of Agboville1; AkpiAgb2 = Akpi of Agoville2; Akpi-Vav = Akpi of Vavoua; Akpi-Div = Akpi of Divo

Figure 3. Multidimensional scaling (MDS) plot analysis conducted with the proximate and element composition data characterizing defatted flours from $R$. heudelotii seeds kernels.

The dimensions (Distance UA in Figure 3) are factors with real meaning that make it possible to explain the differences among groups [60]. The MDS plot (Figure 3) shows that the defatted flours from $R$. heudelotii samples were clearly classified into Bondoukou-Lakota-Vavoua diagram (Akpi-Lak; Akpi-Bon; Akpi-Vav, code sample) and individual samples (Agboville1 diagram, Divo diagram and Agboville2 diagram). Considering the only group composed of the defatted flours from R. heudelotii grown in Bondoukou, Lakota, and Vavoua, it can be observed from the multidimensional positioning graph that the production processes of Bondoukou, Lakota, and Vavoua show strong similarities in separate quadrants. The similarity attributed to phosphorus is observed in similar trends (Table 2), especially for Lakota and Vavoua samples. This similarity is also expressed by the F1 distances expressed to the level in dry matter (0.941188), moisture (0.774839), ash (0.716755), proteins $(0.854214)$, total carbohydrates $(0.895931)$, energy value $(0.930116)$, polyphenols $(0.787436)$, and flavonoids (0.762606). Characteristic distances of similarity agree with data in Tables 1 and 2. From these data, the approximation is more evident between the Lakota and Bondoukou samples on the graph (Figure 3). They have 94.0 and $93.7 \%$ dry matter, respectively, and $12.0 \%$ and $12.2 \%$ ash, respectively, just to mention a few. These data could also be attributed to the fact that the production 
systems of both Lakota and Bondoukou cakes have similar stages, namely pre-cooking stage followed by the renewal of cooking water before the cooking stage, while in Vavoua these steps are not practiced. These observations suggest that the extraction process of kernels from Bondoukou, Lakota, and Vavoua are similar reading from the diagram. Agboville1 samples differed from the others by the MDS output dimensions in terms of dry matter, ash, protein, total carbohydrates, fiber, $\mathrm{pH}$, acidity, and caloric energy. In effect, the difference in the position of this sample on the graph would be related to the average values obtained for quoted parameters. Most of these parameters are the singular values for defatted flours from Agboville1. This sample also differs by the MDS output dimensions in level of polyphenols, phytates, flavonoids, tannins, and oxalates. The dissimilarity with the other samples is shown by the result in Table 3. This sample has the highest content of polyphenols (403.9 $\mathrm{mg} / 100 \mathrm{~g})$ and the lowest tannin content $(16.4 \mathrm{mg} / 100 \mathrm{~g})$, as well as singular contents in phytates $(62.3 \mathrm{mg} / 100 \mathrm{~g})$ and flavonoids $(1.8 \mathrm{mg} / 100 \mathrm{~g})$. The uniqueness of these findings in particular could be justified by the kernels production system. This system includes the step of preliminary drying of the seeds after cooking before the extraction of kernels. This step may influence the contents of the different substances. As for Divo, they differ from the other samples in dry matter, protein, total carbohydrate, and $\mathrm{pH}$. These differences are shown by the average content of these parameters. Divo samples have the highest rate of dry matter $(95.6 \%)$. The differences are also confirmed by the analysis of the variance, which indicates significant differences between the parameters $(p \leq 0.05)($ Table 1$)$. Also, the MDS output distances recorded for polyphenols, phytates, flavonoids, tannins, and oxalates showed how different Divo sample was from the others. The dissimilarities in these parameters, as observed in Table 3, could be particularly attributed to the long pre-cooking time (all night) in the production process of $R$. heudelotii kernels. The difference in the result therefore could be linked to the pre-cooking. The uniqueness of Agboville2 resides in the parameters such as dry matter, proteins, total carbohydrates, $\mathrm{pH}$, polyphenols, phytates, flavonoids, and oxalates. This feature is characterized by the dimensions of MDS output obtained for each of the parameters; the dimensions included between 0.8 and 0.9 . The average dry matter content (92.3\%) illustrates the difference between this sample and the others (Tables 1 and 3). Agboville2 sample had the lowest dry matter content. The dissimilarity in these results could be due to the direct cooking of $R$. heudelotti fruits after their harvest (Figure 2), thus replacing the fermentation stage of the fruits. This cooking of fruits could cause significant changes to the different levels of biochemical parameters of the defatted flours from $R$. heudelotti seeds kernels. Variance analysis confirms these significant differences between the contents for these quoted parameters $(p \leq 0.05)$.

\section{Conclusions}

The results in the present study reaffirm that defatted flours from $R$. heudelotti seeds kernels have high nutrient composition and calorie value, most especially in terms of carbohydrate (total dietary fiber) and protein. Among the mineral elements investigated ( $\mathrm{P} ; \mathrm{Ca} ; \mathrm{K} ; \mathrm{Fe} ; \mathrm{Zn} ; \mathrm{Cl}$ ), magnesium was the predominant mineral, while polyphenols and oxalates were the main phytochemical compounds identified. From these results, the kernel extraction techniques employed may influence the physico-chemical composition and antioxidant potential of defatted flours of $R$. heudelotti seed kernels, particularly the contents of crude protein, total dietary fiber, polyphenols, flavonoids, tannins, and ash (Mg, P, Ca, and $\mathrm{K}$ ). The application of the MDS technique made possible the selection of chemical compounds that are responsible for the main differences among samples. Thus, the MDS technique made possible the selection of four main extraction systems: the Bondoukou-Lakota-Vavoua diagram, the Agboville1 diagram, the Divo diagram, and the Agboville2 diagram. These results provide useful indications of the effect of the traditional extraction process on the physico-chemical and antioxidant compounds of defatted kernels flours from $R$. heudelotti.

Acknowledgments: This research was performed in partial fulfillment of the requirements for a thesis in Food Sciences and Technology. The authors thank three anonymous reviewers for helpful comments that greatly improved an early version of the manuscript. 
Author Contributions: Mamadou Coulibaly is the principle investigator for this research. Mamadou Coulibaly was responsible for the collection of samples and contributed to the chemical analyses. Camille Adam Kouamé contributed to the analyses and to the writing of the manuscript. Nestor Kouakou Kouassi and Kingsley Kwadwo Asare Pereko contributed to the analyses and the revision of the manuscript. Georges N'guessan Amani participated in the design of the study. Denis Y. N'dri was responsible for formulating the research question and reviewed the manuscript. All the authors read and approved the final manuscript.

Conflicts of Interest: The authors declare no conflict of interest.

\section{References}

1. Kouakou, A.K.; Barima, Y.S.S.; Zanh, G.G.; Traoré, K.; Bogaert, J. Inventory and availability of non-timber forest products used by local residents of the classified forest of haut-Sassandra after the armed conflict period in Ivory Coast. Tropicultura 2017, 35, 121-136.

2. Cosyns, H. Ricinodendron heudelotii Kernel Group Commercialization and Its Impact on Farmers' Livelihoods in Cameroon. Ph.D. Thesis, Faculty of Bioscience Engineering, Ghent University, Ghent, Belgium, 2013.

3. Léonard, J. Notulae systematicae XXXII. Observations on African species of Clutia, Ricinodendron and Sapium (Euphorbiaceae). Bull. Jardin Botan. l'État Bruxelles 1961, 31, 391-406. [CrossRef]

4. Assanvo, F.E.; Gogoi, P.; Dolui, K.S.; Baruah, D.S. Synthesis, characterization, and performance characteristics of alkyd resins based on Ricinodendron heudelotii oil and their blending with epoxy resins. Ind. Crops Prod. 2015, 65, 293-302. [CrossRef]

5. Saki, J.S.; Mosso, K.; Sea, B.T.; Diopoh, J.K. Determination of some essential components of Ricinodendron heudelotii (or akpi) in Cote d'Ivoire. Agron. Afr. 2005, 17, 137-142.

6. Mezajoug, K.L.B.; Tchiégang, C. Physico chemical properties of defatted flours from Ricinodendron heudelotii (Bail.) and Tetracarpidium conophorum (müll. arg.) with respect to particle sizes. Glob. Adv. Res. J. Agric. Sci. 2016, 5, 94-102.

7. Tchiégang, C.; Kapseu, C.; Ndjouenkeu, R.; Ngassoum, M.B. Ricinodendron heudelotii (Bail.) kernels: A novel ingredient for tropical food agro-industries. J. Food Eng. 1997, 32, 1-10. [CrossRef]

8. Li, D. Proteins from land plants and potential resources for human nutrition and food security. Trends Food Sci. Technol. 2013, 32, 25-42.

9. Mvomo, E.J. Training report of the basic communities in techniques of valorization of essessang / njansang seeds (Ricinodendron heudelotii). Projet GCP/RAF/441/GER, Strengthening food security in Central Africa through sustainable management of non-timber forest products, 2012; 44p. Available online: http:/ / www. fao.org/docrep/field/009/an902f/an902f00.pdf (accessed on 23 February 2016).

10. Womeni, H.M.; Ndjouenkeu, R.; Kapseu, C.; Tchouanguep Mbiapo, F.; Parmentier, M.; Fanni, J. Effect of Cooking and Drying of Shea Nuts (Butyrospermum parkii (G. Don) Kotschy) on the Quality of Butter. Tropicultura 2006, 24, 175-182.

11. Udo, O.; Ime, A.; Akpan, A.E. Phytochemical screening of Ricinodendron heudelotii (euphorbiaceae) for insecticidal activity in the control of two storage insect pests. Int. J. Adv. Biotechnol. Res. 2017, 7, 156-162.

12. Meva, E.F.; Ebongue, O.C.; Fannang, V.S.; Segnou, L.M.; Ntoumba, A.A.; Kedi, E.P.B.; Loudang, N.R.-E.; Wanlao, Y.A.; Mang, R.E.; Mpondo, M.A.E. Natural substances for the synthesis of silver nanoparticles against Escherichia coli: The Case of Megaphrynium macrostachyum (Marantaceae), Corchorus olitorus (Tiliaceae), Ricinodendron heudelotii (Euphorbiaceae), Gnetum bucholzianum (Gnetaceae), and Ipomoea batatas (Convolvulaceae). J. Nanomater. 2017, 2017, 6834726. [CrossRef]

13. Nzali, G.H.; Tchiegang, C.; Sandjon, B.; Meurens, M. Comparison of some physicochemical properties of oil extracted from Ricinodendron heudelotii (Bail.) kernels by UV spectrophotometer. Int. J. Biosci. 2016, 8, 93-102.

14. Association of Official Analytical Chemists (AOAC). Official Methods of Analysis, 15th ed.; Association of Official Analytical Chemists: Washington, DC, USA, 1990.

15. Joint FAO/WHO Expert Consultation. Carbohydrates in Human Nutrition; FAO Food and Nutrition Paper 66; FAO: Rome, Italy, 14-18 April 1997. Available online: http:/ / www.fao.org/docrep/W8079E/w8079e0a.htm (accessed on 21 August 2016). 
16. Prosky, L.; Asp, N.G.; Schweizer, T.F.; de Vries, J.W.; Furda, I. Determination of insoluble, soluble, and total dietary fiber in foods and food products: Interlaboratory study. J. Assoc. Off. Anal. Chem. 1988, 71, 1017-1023. [PubMed]

17. Dubois, M.; Gilles, K.A.; Hamilton, J.K.; Rebers, P.A.; Smith, F. Colorimetric method for the determination of sugars and related substances. Anal. Chem. 1956, 28, 350-356. [CrossRef]

18. Bernfeld, P. Alpha and beta-amylases. In Methods in Enzymology; Colowick, S.P., Kaplan, N., Eds.; Academic Press: New York, NY, USA, 1955; Volume 1, pp. 149-158.

19. Atwater, W.; Rosa, E. A new respiratory calorimeter and the conservation of energy in human body. Phys. Rev. 1899, 9, 214-251.

20. American Association of Cereal Chemists (AACC). Official Method 40-70.01: Elements by atomic absorption spectrophotometry. In Approved Methods of the American Association of Cereal Chemists, 11th ed.; AACC International: St. Paul, MN, USA, 1999.

21. Fiske, C.H.; Subbarow, Y. The colorimetric determination of phosphorus. J. Biol. Chem. 1925, 66, 375-400.

22. Meda, A.; Laien, C.E.; Romito, M.; Millogo, J.; Nacoulma, O.G. Determination of total phenolic, flavonoid and proline contents in Burkina Faso honeys as well as well as their radical scavenging activity. Food Chem. 2005, 91, 571-577. [CrossRef]

23. Mohammed, A.I.; Ponnamperuma, A.J.P.; Hafez, Y.S. New Chromophore method for phytic acid determination. Am. Assoc. Cereal Chem. 1986, 63, 475-478.

24. Bainbridge, Z.; Tomlins, K.; Westby, A. Methods for Assessing Quality Characteristic of Non-Grains Starch (Part 3. Laboratory Methods); Natural Ressources Institute: Chathom, UK, 1996.

25. Day, R.A.; Underwood, A.L. Quantitative Analysis, 5th ed.; Prentice Hall Publication: London, UK, 1986; pp. 1-701.

26. N’Dri, D.; Mazzeo, T.; Zaupa, M.; Ferracane, R.; Fogliano, V.; Pellegrini, N. Effect of cooking on the total antioxidant capacity and phenolic profile of some whole-meal African cereals. J. Sci. Food Agric. 2013, 93, 29-36. [CrossRef] [PubMed]

27. Singleton, V.L.; Orthofer, R.; Lamuela-Raventos, R.M. Analysis of total phenols and other oxidation substrates and antioxidants by means of Folin-Ciocalteu reagent. Methods Enzymol. 1999, 299, 152-178. [CrossRef]

28. Ogungbenle, H.N.; Oshodi, A.A.; Oladimeji, M.O. The proximate and effect of salt applications on some functional properties of quinoa (Chenopodium quinoa) flour. Pak. J. Nutr. 2009, 8, 49-52. [CrossRef]

29. Yagoub, A.A.; Abdalla, A.A. Effect of domestic processing methods on chemical composition, in vitro digestibility of protein and starch and functional properties of bambara groundnut (Voandzeia subterranea) seed. Res. J. Agric. Biol. Sci. 2007, 3, 24-34.

30. Ragab, D.M.; Babiker, E.E.; El Tinay, A.H. Fractionation, solubility and functional properties of cowpea (Vigna unguiculata) proteins as affected by $\mathrm{pH}$ and/or salt concentration. Food Chem. 2004, 84, 207-212. [CrossRef]

31. Tchiegang, C.; Mezajoug, K.L.; Tenin, D.; Ndjouenkeu, R. Physicochemical and functional properties of defatted cakes from two Euphorbiaceae from Cameroon: Ricinodendron heudelotii (Bail) and Tetracarpidium conophorum (Müll. Arg.). J. Food Technol. 2006, 4, 96-100.

32. Adeoti, O.A.; Alabi, A.O.; Adedokun, S.O.; Jimoh, K.O.; Elutilo, O.O.; Azeez, L.A. Influence of Processing Methods on the Nutrient, Anti-Nutrient, Mineral Compositions and Functional Properties of Akee Apple (Blighia Sapida Konig) Seed and Aril Flour. J. Hum. Nutr. Food Sci. 2017, 5, 1101.

33. Fabbrin, D.T.A.; Crosby, G.A. A review of the impact of preparation and cooking on the nutritional quality of vegetables and legumes. Int. J. Gastron. Food Sci. 2016, 3, 2-11. [CrossRef]

34. Mezajoug, K.L.B.; Arab-Tehrany, E.; Tchiégang, C.; Linder, M. Compositional and nutritional studies of two defatted flours obtained from Ricinodendron heudelotii (Bail.) and Tetracarpidium conophorum (Müll. Arg.). Food 2011, 5, 52-57.

35. D’Evoli, L.; Lucarini, M.; Gabrielli, P.; Aguzzi, A.; Lombardi-Boccia, G. Nutritional Value of Italian Pistachios from Bronte (Pistacia vera, L.), Their Nutrients, Bioactive Compounds and Antioxidant Activity. Food Nutr. Sci. 2015, 6, 1267-1276. [CrossRef] 
36. Ibeji, C.C. Effect of different processing methods on the nutritional composition of three different cultivars of Dioscorea bulbifera. Bachelor's Thesis, Food Science and Technology, Michael Okpara University of Agriculture, Umudike, Nigeria, 2011; p. 29.

37. Fombang, E.N.; Agamou, J.A.A.; Mbofung, C.M.F. Incorporation of Ricinodendron heudolotti meal into blends of wheat and precooked taro flour for production of nutrient dense biscuits. Indian J. Nutr. 2016, 3, 131.

38. Mezajoug, K.B.L. Nutritional and Functional Properties, Concentrate and Isolate Proteins of Ricinodendron Heudelotii Oilseed (Bail). Pierre ex Pax and Tetracarpidium conophorum (Müll. Arg). Ph.D. Thesis, Ecole Nationale Supérieure des Sciences Agro-Industrielles, Laboratoire de Biochimie et Technologie Alimentaire, Nancy, France, 2010; 226p.

39. Chapeland-Leclerc, F.; Papon, N.; Noël, T.; Villard, J. Molds and food risks (Mycotoxicoses). Rev. Franç. Lab. 2000, 373, 61-66.

40. Aletor, V.A.; Aladetimi, O.O. Compositional evaluation of some cowpea varieties and some under-utilized edible legumes in Nigeria. Die Nahrung 1989, 33, 999-1007. [CrossRef] [PubMed]

41. Andualem, B.; Gessesse, A. Proximate composition, mineral content and antinutritional factors of Brebra (Millettia ferruginea) seed flour as well as physicochemical characterization of its seed oil. SpringerPlus 2014, 3, 298. [CrossRef] [PubMed]

42. Bezzala, A. Argan Tree Introduction Test in Amdoukal Area and Evaluation of Some Parameters of Resistance to Drought. Master's Thesis, University El Hadj Lakhdar, Batna, Algeria, 2005; 106p.

43. Pomeranz; Clifton, D. Properties of defatted soybean, peanut field pea and pecan flours. J. Food Sci. 1981, 42, 1440-1450.

44. Mayombo, P.A.; Baldwin, P.; Wathelet, J.; Marlier, M.; Istasse, L. Incorporation of rapeseed meal extracted by pressure in a diet for growing fattening bulls. I. Intake, digestibility and fermentation in the rumen. I. Ingestion, digestibilite et fermentation dans le rumen. Ann. Zootech. INRA/EDP Sci. 1997, 46, 57-70. [CrossRef]

45. Treche, S.; Tchiloemra-Poba, G.; Gallon, J.M. Variation Factors in the Quality of Cassava Jours Produced at the Village Level in the Congo; Agbor Egbe, T., Brauman, A., Griffon, D., Trèche, S., Eds.; Colloques et Séminaires; ORSTOM: Congo, 1995; pp. 450-460. ISBN 2-7099-1279-1. Available online: https:/ / core.ac.uk/download/ pdf/39854995.pdf (accessed on 2 August 2016).

46. Sabo, H.; Sadou, H.S.; Mahamane, L.C-L. Global chemical composition of seeds and physicochemical characteristics of Luffa aegyptiaca and Luffa cylindrica oils from Niger. J. Soc. Ouest-Afr. Chim. 2005, 20, 119-133.

47. Al-wahsh, A.I.; Horner, T.H.; Palmer, G.R.; Reddy, B.M.; Massey, K.L. Oxalate and Phytate of Soy Foods. J. Agric. Food Chem. 2005, 53, 5670-5674. [CrossRef] [PubMed]

48. Sauvant, D.; Perez, J.M.; Tran, G. INRA-AFZ Tables of Composition and Nutritional Value of Feed Materials for Livestock, 2nd ed.; INRA Editions Versailles: Paris, France, 2004; 306p, ISBN 2738011586.

49. Lestradet, H.; Machinot, S. Daily calcium intake. Cah. Nutr. Diet. 1990, 25, 135-137.

50. FAO/WHO. Requirement of Vitamin A, Iron, Folate and Vitamin B12; Report of a Joint Expert Consultation; FAO/WHO: Rome, Italy, 1988.

51. Vasco, C.; Ruales, J.; Kamal-Eldin, A. Total phenolic compounds and antioxidant capacities of major fruits from Ecuador. Food Chem. 2008, 111, 816-823. [CrossRef]

52. Mehinagic, E.; Bourles, E.; Jourjon, F. Nutritional quality of fruits: Impact of processing on phenolic compounds. Rev. Suisse Vitic. Arboric. Horticult. 2011, 43, 364-368.

53. Odinga, T.; Worlu-Wodu, Q.E.; Deekae, S. Bioprospective Screening of Ricinodendron Heudelotii Seeds. J. Anal. Pharm. Res. 2016, 3, 84. [CrossRef]

54. Bolanho, B.C.; Beléia, A.P. Bioactive compounds and antioxidant potential of soy products. Alim. Nutr. Araraquara 2011, 22, 539-546.

55. Sowndhararajan, K.; Siddhuraju, P.; Manian, S. Antioxidant and free radical scavenging capacity of the underutilized legume, Vigna vexillata (L.) A. rich. J. Food Compos. Anal. 2011, 24, 160-165. [CrossRef]

56. Gill, L.S. Ethnomedical Uses of Plants in Nigeria; University of Benin: Benin City, Nigeria, 1992; pp. 1-268.

57. Zhang, M.; Hettiarachchy, S.N.; Horax, R.; Kannan, A.; Praisoody, M.D.A.; Muhundan, A.; Mallangi, C.R. Phytochemicals, antioxidant and antimicrobial activity of Hibiscus sabdariffa, Centella asiatica, Moringa oleifera and Murraya koenigii leaves. J. Med. Plants Res. 2011, 5, 6672-6680. 
58. N’Dri, Y.D.; Kouakou, K.N.; Erba, D.; Scazzina, F.; Pellegrini, N.; Casiraghi, C.M. Nutritive Evaluation of the Bambara Groundnut Ci12 Landrace (Vigna subterranea (L.) Verdc. (Fabaceae)) Produced in Côte d'Ivoire. Int. J. Mol. Sci. 2015, 16, 21428-21441.

59. Fekadu, H.; Beyene, F.; Desse, G. Effect of traditional processing methods on nutritional composition and anti-nutritional factors of anchote (Coccinia Abyssinica (lam.) Cogn) tubers grown in Western Ethiopia. J. Food Process. Technol. 2013, 4, 249. [CrossRef]

60. Suárez, M.H.; Hernández, A.I.M.; Galdón, B.R.; Rodríguez, L.H.; Cabrera, C.E.M.; Mesa, D.R.; Rodríguez Rodríguez, E.M.; Romero, C.D. Application of multidimensional scaling technique to differentiate sweet potato (Ipomoea batatas (L.) Lam) cultivars according to their chemical composition. J. Food Compos. Anal. 2016, 46, 43-49. [CrossRef]

(C) 2018 by the authors. Licensee MDPI, Basel, Switzerland. This article is an open access article distributed under the terms and conditions of the Creative Commons Attribution (CC BY) license (http:/ / creativecommons.org/licenses/by/4.0/). 